\title{
Impact of Organic and Inorganic Source of Nutrients on Growth and Yield of Basmati Rice under SRI
}

\author{
Ankita Rao*, N. B. Singh and Deepak Pandey \\ Department of Agronomy, A.N.D. University of Agricultural Technology, Kumarganj, \\ Ayodhya-224229, India \\ *Corresponding author
}

\begin{tabular}{|l|}
\hline K e y w o r d s \\
Basmati rice, Grain \\
Yield, Growth, \\
$\begin{array}{l}\text { Inorganic fertilizers } \\
\text { and organic } \\
\text { manures }\end{array}$ \\
\hline Article Info \\
\hline $\begin{array}{l}\text { Accepted: } \\
\text { 14 November } 2019 \\
\text { Available Online: } \\
\text { 10 December } 2019\end{array}$ \\
\hline
\end{tabular}

\section{Introduction}

Rice (Oryza sativa L.) is one of the most important stable food crops in the world. It belongs to family Poaceae (Gramineae). It is a high calorie food which contains $75 \%$ starch, 6-7\% protein, $2-2.5 \%$ fat, $0.8 \%$ cellulose and 5-9 \% ash. In Asia, more than two billion people are getting $60-70 \%$ of their energy requirement from rice and its derived products. Rice is cultivated world-wide over an area of about 160.68 million ha ${ }^{-1}$ with an annual production of about 650.19 million tonnes. In India rice is cultivated over an area of about 39.16 million hectares with an annual production of about 85.59 million tones and the productivity of 2.20 tonnes $\mathrm{ha}^{-1}$. Utter Pradesh is an important rice growing state in 
the country. The area and production of rice in this state is about 13.84 million hectare and 14.00 million tonnes respectively with an average production of 2.35 tonnes (Tomar et al., 2018). Further, to sustain present food self- sufficiency and to meet future food requirements, India has to increase its rice productivity by 3 percent per annum. Rice cultivation requires large quantity of water and for producing one $\mathrm{kg}$ rice, about 3000-5000 litres of water is required depending on the different rice cultivation methods such as transplanted rice, direct sown rice (wet seeded), alternate wetting and drying method (AWD), system of rice intensification (SRI) and aerobic rice, respectively. Application of inorganic fertilizers alone could not sustain the soil fertility and productivity under cropping sequences. There are valuable benefits of integrated nutrient management over sole application of the individual fertilizer sources in improving yield and nutrient uptake and properties of the soil in rice based cropping system (Wolie and Admassu, 2016). Valuable benefits of The price of inputs, mainly inorganic fertilizers, is increasing day by day, therefore emphasis is needed to maximize the nutrient-use efficiency and grain yield, and minimize the cost of production. The efficiency of applied nutrient may be raised by the combined use of organic and inorganic fertilizers or supplying the nutrients at the peak period of absorption.

\section{Materials and Methods}

The present experiment was conducted during Kharif season 2017 and 2018 at Agronomy Research Farm in Narendra Deva University of Agriculture \& Technology, Kumarganj, Ayodhya. The experimental soil was silty loam with $\mathrm{pH}$ (8.30 and 8.29) having low organic carbon (0.31 and $0.32 \%$ ), available nitrogen (180.20 and $\left.182.82 \mathrm{~kg} \mathrm{ha}^{-1}\right)$ and medium in available phosphorus (13.70 and $13.80 \mathrm{~kg} / \mathrm{ha})$ and high in potassium $(208.22$ and $212.32 \mathrm{~kg} / \mathrm{ha}$ ). The experiment was laid out in randomized block design with three replications. The experiment included ten treatments, viz. $\mathrm{T}_{1}-$ Control, $\mathrm{T}_{2-}-100 \% \mathrm{RDF}$, $\mathrm{T}_{3}-125 \%$ RDF, $\quad \mathrm{T}_{4}-150 \% \quad \mathrm{RDF}, \quad \mathrm{T}_{5}-75 \%$ $\mathrm{RDF}+25 \% \mathrm{FYM}, \mathrm{T}_{6}-75 \% \mathrm{RDF}+25 \% \mathrm{VC}, \mathrm{T}_{7^{-}}$ $100 \% \mathrm{RDF}+25 \% \mathrm{FYM}, \mathrm{T}_{8}-100 \% \mathrm{RDF}+25 \%$ $\mathrm{VC}, \mathrm{T}_{9^{-}} 125 \% \mathrm{RDF}+25 \% \mathrm{FYM}$ and $\mathrm{T}_{10^{-}}-125 \%$ $\mathrm{RDF}+25 \% \mathrm{VC}$. Potassium in the form of muriate of potash was applied at planting; the crop received nitrogen in the form of half as basal and the rest half dose of nitrogen was top dressed in two splits i.e. after first at 45 and second 60 days after transplanting. Phosphorus was applied as DAP at transplanting. Well decomposed farmyard manure $(0.51 \% \mathrm{~N}, 0.25 \% \mathrm{P}$ and $0.55 \% \mathrm{~K})$ and vermicompost $(2.5 \% \mathrm{~N}, 1.5 \% \mathrm{P}$ and $1.5 \% \mathrm{~K})$ were applied as per the treatments two week before transplanting. The seedlings of rice, $\mathrm{cv}$. Pusa Basmati-1 were transplanted in first week of July by keeping planting geometry of $25 \times 25 \mathrm{~cm}$ with the seed rate $4 \mathrm{~kg} / \mathrm{ha}$. The crop was harvested second week of November during 2017 and 2018, respectively. The observations on growth attributes, yield attributes and yields of the crops were recorded through standard procedures. Plant samples (grain and straw) were collected at harvest and analyzed for NPK uptake. The data were statistically analyzed by using statistical procedures and comparisons were made at $5 \%$ level of significance.

\section{Results and Discussion}

\section{Growth and yield attributes}

Addition of various sources of organic manures along with inorganic fertilizers influenced growth characters of basmati rice positively (Table 1 and 2). Application of $125 \% \mathrm{RDF}+25 \% \mathrm{VC}$ improved the growth and yield attributes significantly over control, and relatively higher values of these parameters were recorded with $125 \%$ 
RDF $+25 \%$ VC. This could be due to availability of nutrients in balanced and adequate amounts. The crop receiving higher amounts of nutrients through organic or inorganic nutrient sources recorded higher plant height and number of tillers/hill.

Among the nutrient management practices, application of $125 \% \mathrm{RDF}+25 \% \mathrm{VC}$ produced taller plants (103.0 and $104.57 \mathrm{~cm})$, higher number of tillers/hill (20.68 and 21.96), dry matter accumulation (820.44 and $821.35 \mathrm{gm}^{-}$ $\left.{ }^{2}\right)$, length of panicles $(25.0$ and $26.18 \mathrm{~cm})$, grains/panicle (197.0 and 198.04), test weight (23.02 and $23.97 \mathrm{~g}$ ) during both the years, respectively. The lowest values of these growth and yield attributes were recorded under control. Adequate and continuous availability of nutrients with NPK or combined use of organic manures with NPK might have improved the growth and yield attributes of basmati rice crop (Tomar et al., 2018). The addition of organic manure significantly influenced the beneficial microorganisms to colonize in rhizosphere and stimulate plant growth by providing necessary nutrients besides synthesizing some plant hormones Venkatasalam et al., (2012); which may be the reason for increase in growth and yield attributes in treatments supplied with organic manures.

\section{Productivity}

The grain and straw yields of basmati rice exhibited significant variation due to different nutrient management practices (Table 2). Application of $125 \% \quad \mathrm{RDF}+25 \% \mathrm{VC} \quad\left(\mathrm{T}_{10}\right)$ recorded the highest grain (56.50 and 59.00 $\mathrm{q} / \mathrm{ha}$ ) and straw yield (75.93 and $78.43 \mathrm{q} / \mathrm{ha})$ and found statistically at par with $\mathrm{T}_{8}$ and $\mathrm{T}_{\mathbf{9}}$. The lowest grain yield (28.24 and $28.74 \mathrm{q} / \mathrm{ha})$ and straw yield (55.02 and $55.52 \mathrm{q} / \mathrm{ha})$ of basmati rice were recorded in $T_{1}$ (control) during both the cropping season, respectively. These trends are in consonance with earlier reports of Tomar et al., (2018).

\section{Total nutrient uptake}

The total uptake $\mathrm{N}, \mathrm{P}$ and $\mathrm{K}$ by basmati rice varied significantly under different nutrient management practices (Table 3). Integrated nutrient management practices $\left(\mathrm{T}_{\mathbf{1 0}}\right)$ recorded significantly higher uptake of N (120.57 and $\left.125.90 \mathrm{~kg} \mathrm{ha}^{-1}\right), \mathrm{P}\left(34.67\right.$ and $\left.36.40 \mathrm{~kg} \mathrm{ha}^{-1}\right)$ and $\mathrm{K}\left(119.13\right.$ and $\left.146.43 \mathrm{~kg} \mathrm{ha}^{-1}\right)$ which was significantly superior to all the rest of the treatments and the lowest uptake of $\mathrm{N}(60.16$ and $\left.61.54 \mathrm{~kg} \mathrm{ha}^{-1}\right), \mathrm{P}\left(14.85\right.$ and $\left.15.63 \mathrm{~kg} \mathrm{ha}^{-1}\right)$ and $\mathrm{K}$ (68.61 and $78.51 \mathrm{~kg} \mathrm{ha}^{-1}$ ) was recorded under control plots during both the years, respectively. The higher uptake of nutrients under integrated nutrient management $\left(\mathrm{T}_{9}\right.$ and $\mathrm{T}_{10}$ ) was ascribed to continuous supply of nutrients throughout the crop growth period as the nutrients from inorganic sources were readily available to the crop in the early stages besides the slow and continuous release of nutrients from the organic source made available at later stages of the crop growth. Higher uptake of $\mathrm{N}, \mathrm{P}$ and $\mathrm{K}$ under organicinorganic nutrient combination was also reported by Pandey et al., (2007) in rice.

\section{Economics}

Economic analysis reveals that the net returns and $\mathrm{B}: \mathrm{C}$ ratio of basmati rice differed noticeably in different nutrient management options (Table 2) and that was directly related to the price of the crop produce and cost incurred on nutrient inputs under different treatments. The highest net returns of basmati rice (Rs $79976.78 \mathrm{Rs} / \mathrm{ha}$ ) were recorded in $\mathrm{T}_{10}-125 \% \mathrm{RDF}+25 \% \mathrm{VC}$ followed by $\mathrm{T}_{9}$. 
Table.1 Effect of different nutrient management practices on plant height (cm), number of tillers hill ${ }^{-1}$, dry matter accumulation gm ${ }^{-2}$, length of panicles $(\mathrm{cm})$ and grains/panicle of basmati rice

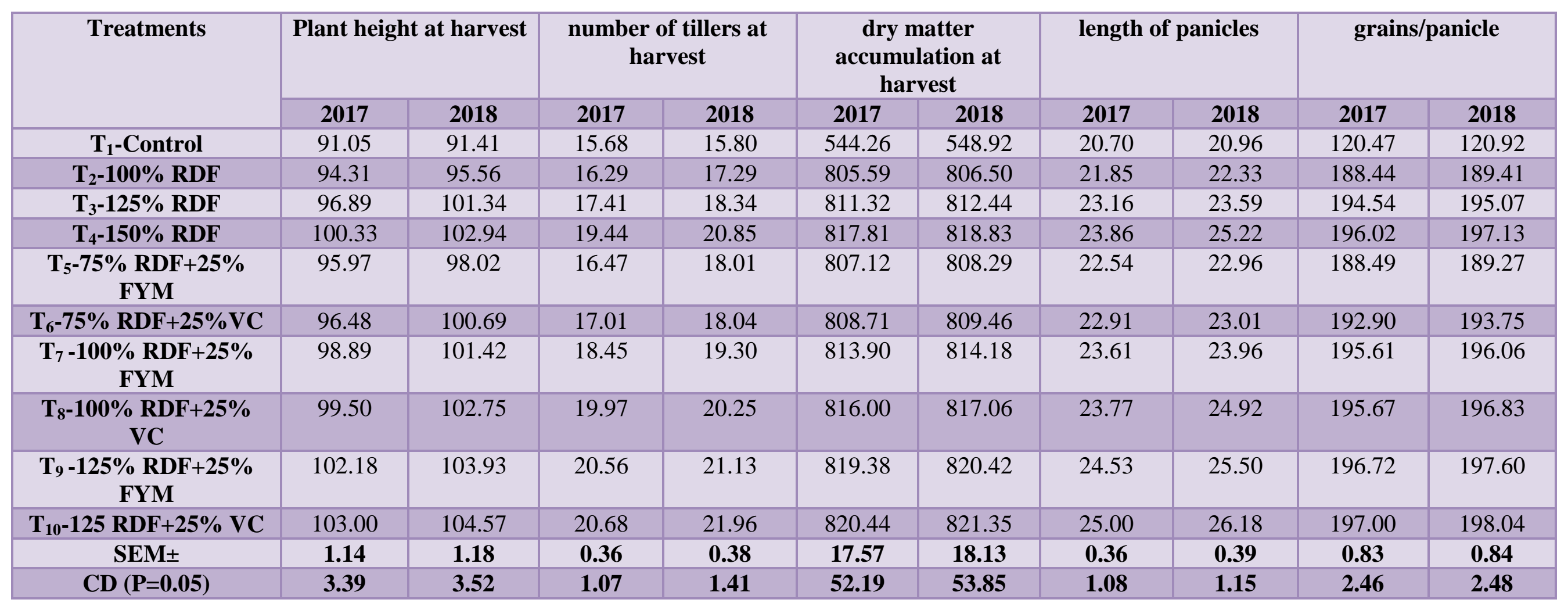


Table.2 Effect of different nutrient management practices on test weight (g), grain yield (q/ha), straw yield (q/ha), net return (Rs./ha) and B:Cratio (pooled of two season data) of basmati rice

\begin{tabular}{|c|c|c|c|c|c|c|c|c|}
\hline \multirow[t]{2}{*}{ Treatments } & \multicolumn{2}{|c|}{ test weight } & \multicolumn{2}{|c|}{ grain yield } & \multicolumn{2}{|c|}{ straw yield } & \multirow[t]{2}{*}{ net returns } & \multirow[t]{2}{*}{ B:C ratio } \\
\hline & 2017 & 2018 & 2017 & 2018 & 2017 & 2018 & & \\
\hline $\mathbf{T}_{1}$-Control & 19.08 & 19.73 & 28.24 & 28.74 & 55.02 & 55.52 & 33841.46 & 1.27 \\
\hline$T_{2}-100 \%$ RDF & 19.66 & 20.61 & 43.95 & 44.70 & 62.32 & 63.07 & 56957.83 & 1.74 \\
\hline $\mathrm{T}_{\mathbf{4}}-\mathbf{1 5 0} \%$ RDF & 22.51 & 22.65 & 52.07 & 53.47 & 70.61 & 72.01 & 70877.13 & 2.01 \\
\hline $\begin{array}{c}\mathrm{T}_{5}-75 \% \mathrm{RDF}+25 \% \\
\text { FYM }\end{array}$ & 20.06 & 21.31 & 44.02 & 44.82 & 64.06 & 64.86 & 53215.71 & 1.44 \\
\hline $\begin{array}{c}\mathrm{T}_{7}-100 \% \text { RDF }+25 \% \\
\text { FYM }\end{array}$ & 21.05 & 22.13 & 48.28 & 49.28 & 66.91 & 67.91 & 60033.78 & 1.57 \\
\hline $\begin{array}{c}\mathrm{T}_{8}-100 \% \mathrm{RDF}+25 \% \\
\text { VC }\end{array}$ & 21.52 & 22.51 & 51.48 & 52.68 & 69.00 & 70.20 & 69991.78 & 2.02 \\
\hline $\begin{array}{c}\text { T }_{9}-125 \% \text { RDF }+25 \% \\
\text { FYM }\end{array}$ & 22.90 & 23.89 & 54.52 & 56.42 & 73.43 & 75.33 & 71665.58 & 1.80 \\
\hline
\end{tabular}


Table.3 Effect of different nutrient management practices on total uptake of $\mathrm{N}, \mathrm{P}$ and $\mathrm{K}$ ( $\mathrm{kg} / \mathrm{ha}$ ) of basmati rice

\begin{tabular}{|c|c|c|c|c|c|c|}
\hline \multirow{2}{*}{ Treatments } & \multicolumn{2}{|c|}{ total uptake of $\mathbf{N}$} & \multicolumn{2}{|c|}{ total uptake of $P$} & \multicolumn{2}{|c|}{ total uptake of $K$} \\
\hline & 2017 & 2018 & 2017 & 2018 & 2017 & 2018 \\
\hline $\mathbf{T}_{1}$-Control & 60.16 & 61.54 & 14.85 & 15.63 & 68.61 & 78.51 \\
\hline$T_{2}-100 \%$ RDF & 90.71 & 92.35 & 23.35 & 23.86 & 85.51 & 101.91 \\
\hline $\mathrm{T}_{3}-125 \% \mathrm{RDF}$ & 97.42 & 99.36 & 26.26 & 26.98 & 94.04 & 113.04 \\
\hline $\mathrm{T}_{\mathbf{4}}-\mathbf{1 5 0} \% \mathrm{RDF}$ & 110.59 & 113.53 & 31.32 & 32.35 & 110.32 & 133.05 \\
\hline $\begin{array}{c}\mathrm{T}_{5}-75 \% \mathrm{RDF}+25 \% \\
\text { FYM }\end{array}$ & 92.09 & 93.82 & 24.35 & 24.90 & 88.91 & 105.65 \\
\hline $\mathrm{T}_{6}-75 \% \mathrm{RDF}+25 \% \mathrm{VC}$ & 95.00 & 96.86 & 25.12 & 25.75 & 92.15 & 110.06 \\
\hline $\begin{array}{c}\text { T }_{7}-100 \% \text { RDF }+25 \% \\
\text { FYM }\end{array}$ & 100.89 & 103.00 & 27.58 & 28.93 & 100.45 & 120.24 \\
\hline $\begin{array}{c}\mathrm{T}_{8}-100 \% \mathrm{RDF}+25 \% \\
\mathrm{VC}\end{array}$ & 106.80 & 109.49 & 29.76 & 31.06 & 107.11 & 128.83 \\
\hline $\begin{array}{c}\mathrm{T}_{9}-125 \% \text { RDF }+25 \% \\
\text { FYM }\end{array}$ & 116.00 & 119.87 & 33.00 & 34.36 & 114.90 & 139.80 \\
\hline $\mathrm{T}_{10}-125 \mathrm{RDF}+25 \% \mathrm{VC}$ & 120.57 & 125.90 & 34.67 & 36.40 & 119.13 & 146.43 \\
\hline SEM \pm & 0.86 & 0.87 & 0.36 & 0.37 & 0.81 & 1.10 \\
\hline $\mathrm{CD}(\mathrm{P}=0.05)$ & 2.55 & 2.85 & 1.07 & 1.09 & 2.42 & 3.20 \\
\hline
\end{tabular}


Higher net returns may be attributed to a higher grain yield. Among the various nutrient treatments, maximum $\mathrm{B}: \mathrm{C}$ ratio of 2.22 was recorded under $125 \% \mathrm{RDF}+25 \%$ VC. Similar results were reported by Barik et al., (2008). The minimum values of net returns (Rs. $33841.46 \mathrm{Rs} / \mathrm{ha}$ ) and $\mathrm{B}: \mathrm{C}$ ratio (1.27) were recorded under control due to poor yield of rice.

\section{References}

Barik A.K, Raj A and Saha R K. (2008).Yield performance, economics and soil fertility through organic farming sources (vermicompost) of nitrogen as substitute to chemical fertilizers in wet season rice. Crop Research 36 (1, 2 \& 3): 4-7.

Pandey, N., Verma, A.K., Anurag and Tripathi, R.S. (2007). Effect of integrated nutrient management in transplanted hybrid rice (Oryza sativa). Indian Journal of Agronomy, 52(1): 40-42.

Tomar, R., Singh, N.B., Singh, V., and Kumar, D. (2018). Effect of planting methods and integrated nutrient management on growth parameters, yield and economics of rice. Journal of Pharmacognosy and Phytochemistry, 7(2): 520-527.

Venkatasalam, E.P., Singh, S. and Sharma, S. (2012). Effect of organic manures on yield and yield attributing characters of potato. Potato Journal 39(1): 84-7.

Woliel, A. W., Admassu, M.A. (2016). Effects of integrated nutrient management on rice (Oryza sativa L) yield and yield attributes, nutrient uptake and some physico-chemical properties of soil. Journal of Biology, Agriculture and Healthcare, 6(5): 193-198.

\section{How to cite this article:}

Ankita Rao, N. B. Singh and Deepak Pandey. 2019. Impact of Organic and Inorganic Source of Nutrients on Growth and Yield of Basmati Rice under SRI. Int.J.Curr.Microbiol.App.Sci. 8(12): 1728-1734. doi: https://doi.org/10.20546/ijcmas.2019.812.208 